\title{
Control of Cell Survival in Adult Mammalian Neurogenesis
}

\author{
H. Georg Kuhn \\ Center for Brain Repair and Rehabilitation, Department of Neuroscience and Physiology, University \\ of Gothenburg, Gothenburg 413 90, Sweden \\ Correspondence: georg.kuhn@neuro.gu.se
}

\begin{abstract}
The fact that continuous proliferation of stem cells and progenitors, as well as the production of new neurons, occurs in the adult mammalian central nervous system (CNS) raises several basic questions concerning the number of neurons required in a particular system. Can we observe continued growth of brain regions that sustain neurogenesis? Or does an elimination mechanism exist to maintain a constant number of cells? If so, are old neurons replaced, or are the new neurons competing for limited network access among each other? What signals support their survival and integration and what factors are responsible for their elimination? This review will address these and other questions regarding regulatory mechanisms that control cell-death and cell-survival mechanisms during neurogenesis in the intact adult mammalian brain.
\end{abstract}

\section{ARE NEUROGENIC BRAIN REGIONS EXPANDING DESPITE SPACE LIMITATIONS?}

$\mathrm{T}_{\mathrm{a}}^{\mathrm{h}}$ his question was addressed several decades ago following the first evidence for adult mammalian neurogenesis (Altman and Das 1965). Total neuronal cell counts of the olfactory bulb $(\mathrm{OB})$ and dentate gyrus at different ages revealed that continued growth of the granule cell layers occurs in both regions throughout the adult life. From 1 month until 1 year of age, the number of dentate gyrus granule cells doubled in the rat (Bayer 1982; Bayer et al. 1982). A rise in total volume, as well as increased cell density, contributed to this phenomenon. In the rat $\mathrm{OB}$, a linear growth of the granule cell layer was observed with age, as the number of olfactory granule cells doubled between 3 and 31 months of age (Kaplan et al. 1985).
Considering this substantial growth, we could postulate that new neurons are certainly added to the system. However, the estimated amount of new neurons generated in the adult brain is lower than extrapolated from acute labeling studies using bromodeoxyuridine (BrdU) or cell-cycle markers. This indicates that elimination mechanisms are also present in the neurogenic zone.

\section{PROGRAMMED CELL DEATH IS A COMMON ELEMENT DURING ADULT NEUROGENESIS}

During development, programmed cell death (herein also referred to as apoptosis) is involved in the optimal matching of a neuronal population with available synaptic targets (Buss et al. 2006). Programmed cell death has been shown

Editors: Fred H. Gage, Gerd Kempermann, and Hongjun Song

Additional Perspectives on Neurogenesis available at www.cshperspectives.org

Copyright (C) 2015 Cold Spring Harbor Laboratory Press; all rights reserved; doi: 10.1101/cshperspect.a018895

Cite this article as Cold Spring Harb Perspect Biol 2015;7:a018895 
H.G. Kuhn

to allow for the rapid elimination of neurons that have failed to make proper connections or to secure sufficient amounts of target-derived trophic factors (Oppenheim 1991). Apoptosis has been shown within the neurogenic zones of the postnatal and adult brain (Biebl et al. 2000; Dayer et al. 2003). Quantitatively, the highest number of dying cells was observed in the $\mathrm{OB}$, followed by the rostral migratory stream (RMS), the subventricular zone (SVZ), and the dentate gyrus (Biebl et al. 2000). The location of apoptotic profiles indicated that apoptosis was intimately connected to the generation of new neurons (see Fig. 1).

A large majority of the apoptotic cells are immature (Seki 2002). In the dentate gyrus, the majority of cell death is detected in the subgranular zone (SGZ), the border between the granule cell layer and hilus, in which dividing progenitors reside. Apoptotic profiles have been shown by colabeling with immature neuronal markers, such as doublecortin (DCX) (Kuhn et al. 2005). When monitoring cohorts of adult-born BrdU-labeled cells over time, a $30 \%$ to $70 \%$ reduction in the number of progenitors and young neurons was detected over a period of several months (Winner et al. 2002; Dayer et al. 2003). After this critical period, most adult-born neurons survive for the remainder of the animal's lifespan. For neurons generated during the postnatal period, even higher frequencies of elimination have been reported (Dayer et al. 2003; Kim et al. 2011), although developmentally produced neurons numerically dominate the dentate gyrus granule cell population during adulthood (Lagace et al.
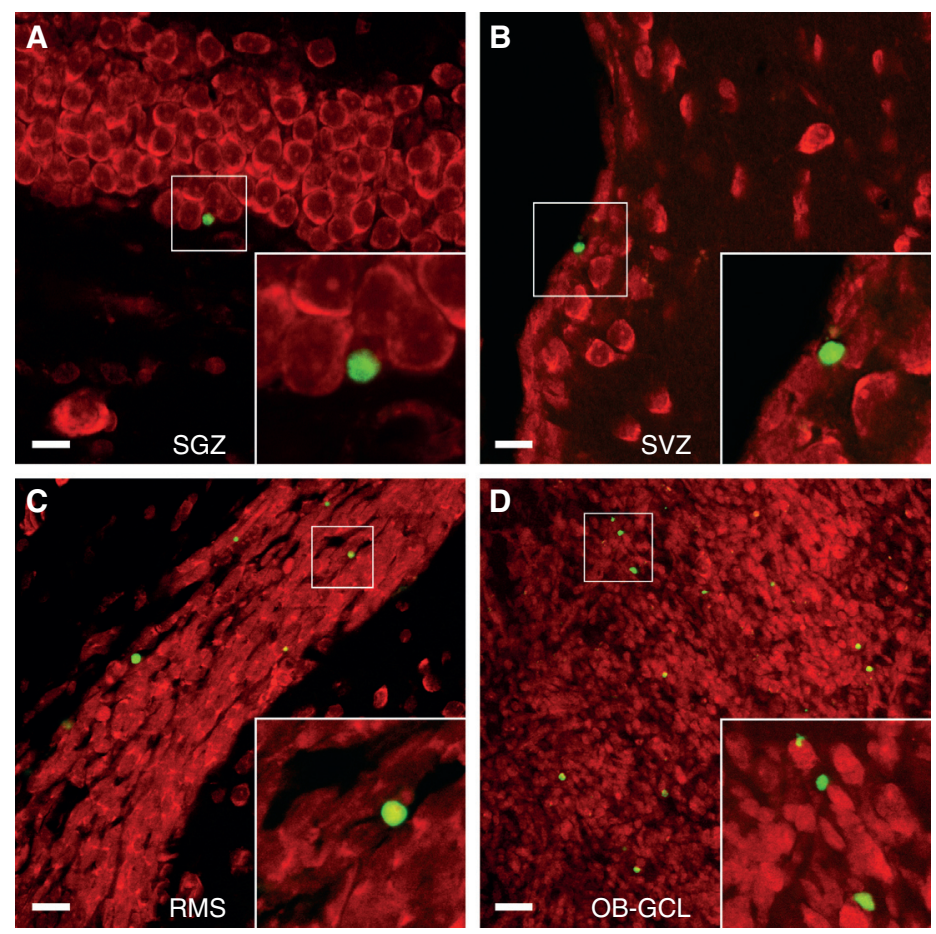

Figure 1. Apoptotic cells can be visualized by terminal deoxynucleotidyl-mediated dUTP nick-end-labeling (TUNEL) in sections of the intact adult rodent brain. TUNEL-positive cells (green) can be frequently detected in (A) the subgranular zone (SGZ) of the dentate gyrus, $(B)$ the subventricular zone (SVZ) of the lateral ventricle wall, $(C)$ the rostral migratory stream (RMS), and $(D)$ the granule cell layer of the olfactory bulb granule cell layer (OB-GCL). Red counterstain is propidium iodide (for more details, see Biebl et al. 2000; Cooper-Kuhn and Kuhn 2002; Kuhn et al. 2005). Scale bars, $15 \mu \mathrm{m}(A-C) ; 50 \mu \mathrm{m}(D)$. 
2007; Muramatsu et al. 2007; Ninkovic et al. 2007).

\section{INTRACELLULAR CELL-DEATH MECHANISMS}

Numerous studies have reported survival-promoting activities and signals in adult neurogenesis. This assumption is often based on increased numbers of BrdU-labeled cells at later time points, albeit initially similar numbers of proliferating cells. However, proliferation and neuronal maturation of progenitor cells are closely intertwined with cell-death mechanisms, which makes it difficult to distinguish whether a net increase in neurogenesis is caused by a prolonged proliferative phase, a shift of multipotent progenitor cells toward increased neuronal lineage commitment, or decreased cell death. More definitive is the quantification of cell-death indicators, such as fragmented nuclei, pycnotic cells, terminal deoxynucleotidylmediated dUTP nick-end-labeling (TUNEL), activation of caspases, or expression of proand antiapoptotic proteins (Gould et al. 1991; Corotto et al. 1994; de Bilbao et al. 1999; Biebl et al. 2000).

Apoptosis is initiated by intracellular signaling pathways in response to cellular stress, which leads to activation of the cysteine-dependent aspartate proteases (caspases) followed by nuclear DNA fragmentation and cell death. Caspase-dependent apoptosis is thought to be a major contributor to cell death in the neurogenic niches. In vivo treatment with caspase inhibitors has been shown to increase the survival rate of newly generated neurons (Biebl et al. 2005; Gemma et al. 2007). Upstream of the caspase cascade, pro- and antiapoptotic signals are integrated by members of the Bcl-2 family. The major proapoptotic molecules, Bax and Bak, compromise the mitochondrial membrane integrity by forming channels that can release apoptogenic signals such as cytochrome $c$. The antiapoptotic proteins, Bcl-2 and Bcl-xL, protect the mitochondrial membrane by forming heterodimers with proapoptotic proteins, thus preventing the release of cytochrome $c$ (Renault et al. 2013).
In adult neurogenesis, it appears that both pro- and antiapoptotic Bcl-2 family members are involved. Bax-deficient mice have a higher number of neuronal progenitor cells and a higher rate of neurogenesis in the dentate gyrus, as well as reduced cell death. The lack of apoptosis leads to an increased accumulation of granule cells and a larger dentate gyrus with age (Sun et al. 2004). Bax-deficient mice, as well as double-knockout mice for Bax and Bak, display a significantly larger pool of neural progenitor cells in the SVZ, which can serve as multipotent stem cells in vitro (Lindsten et al. 2003; Shi et al. 2005). Fewer apoptotic cells were also found in the $\mathrm{OB}$ of Bax knockout and Bax/Bak doubleknockout mice; however, increased OB neurogenesis was less than expected because of decreased migration of SVZ progenitor cells via the rostral migratory stream (Lindsten et al. 2003; Kim et al. 2007). In the dentate gyrus of Bax-deficient mice, because of an absence of elimination, accumulating granule cells show somatic atrophy, reduced dendritic complexity, and synaptic connectivity, indicating that programmed cell death is required for normal hippocampal maturation (Sun et al. 2004; Kim et al. 2009). Induction of Bax expression in progenitor cells of the adult brain increased the number of granule cells in the dentate gyrus (Sahay et al. 2011). These mice show enhanced pattern separation, indicating that the rescued neurons contribute to improved hippocampal function.

$\mathrm{Bcl}-2$ expression is also intimately linked to neurogenesis in the adult brain, with high levels in the SVZ and dentate gyrus (Bernier and Parent 1998; Bernier et al. 2000). Similar to Baxdeficiency, transgenic overexpression of Bcl-2 in neuronal cells results in increased hippocampal neurogenesis caused by reduced cell death of neuronal progenitor cells (Kuhn et al. 2005; Sasaki et al. 2006). The cAMP response elementbinding (CREB) protein signaling pathway has also been reported to alter cell death of adultborn neurons (Jagasia et al. 2009; Herold et al. 2011). CREB signaling is responsible for maintaining the neuronal differentiation program of progenitor cells, which includes expression of survival-promoting factors (Zhang et al. 2009). 
H.G. Kuhn

\section{EXTRACELLULAR SIGNALING}

The survival-promoting effect of neurotrophic factors, hormones, and other extracellular signals is ultimately mediated by interference with apoptosis-inducing signaling pathways. Trophic factors, such as fibroblast growth factor (FGF)-2, brain-derived neurotrophic factor (BDNF), granulocyte colony-stimulating factor (G-CSF), and vascular endothelial growth factor (VEGF), can directly stimulate expression of antiapoptotic Bcl-2 family proteins (Fig. 2) (Bryckaert et al. 1999; Desire et al. 2000; RiosMunoz et al. 2005; Cao et al. 2006; Solaroglu et al. 2006; Milosevic et al. 2007), thereby counteracting Bax and Bak functions and preventing caspase activation.

\section{Neurotrophic Factors and Growth Factors}

The neurotrophin family (nerve growth factor [NGF], BDNF, neurotrophin [NT]3, and NT4/ 5 ) is involved in the development and maintenance of a variety of neuronal cell types through multiple cell mechanisms. In the classical view, neurotrophins are released by target structures, acting as neurite-attracting molecules (Lewin and Barde 1996). On reaching the target, neurons soon become dependent on retrogradely transported neurotrophins for their survival (Oppenheim 1989). Target-independent roles of paracrine- and autocrine-released neurotrophins have also been described (Acheson and Lindsay 1996).

For adult neurogenesis, BDNF appears to play a central role in stimulating the differentiation and survival of newly generated neurons in the SVZ and the hippocampus (Zigova et al. 1998; Benraiss et al. 2001; Scharfman et al. 2005; Rossi et al. 2006). Paradoxically, central nervous system (CNS) depletion of BDNF in mice reportedly induced hippocampal cell proliferation without affecting cell survival or fate specification, suggesting a role in cell-cycle exit and maturation rather than cell death (Chan et al. 2008). Although it is less well studied, NGF was shown to promote neurogenesis following infusion into the lateral ventricle (Frielingsdorf et al. 2007). NT3 also appears to be involved, because adult NT3-deficient mice show impaired granule cell differentiation in the dentate gyrus, despite normal proliferation (Shimazu et al. 2006).

FGF-2, produced and release by astrocytes (Gomez-Pinilla et al. 1992), is an important regulator of adult neurogenesis, and FGF-2 infusion leads to increased neurogenesis (Kuhn et al. 1997; Wagner et al. 1999) by stimulating proliferation. In contrast, FGF receptor $1-$ deficient mice show impaired neurogenesis in the adult hippocampus (Zhao et al. 2007). Interestingly, in mouse slice cultures, FGF-2 deficiency results in no deficiency in proliferation, but rather increased cell death (Werner et al. 2011).

Similarly, a variety of growth factors are known to affect adult neurogenic regions. A subset of these peptides, such as epidermal growth factor (EGF), transforming growth factor (TGF)- $\beta 1$, leukemia-inhibiting factor, and pigment epithelium-derived factor, act only on proliferation and self-renewal of stem cells (Craig et al. 1996; Kuhn et al. 1997; Jin et al. 2002; Buckwalter et al. 2006; Ramirez-Castillejo et al. 2006; Wachs et al. 2006). Although EGF expands the pool of radial glia-like neural stem cells on the expense of neurogenesis, betacellulin (BTC), a member of the EGF family, induces expansion of neuroblastoma-spinal cords (NSCs) and neuroblasts, and promotes neurogenesis in the OB and dentate gyrus (Kuhn et al. 1997; Gomez-Gaviro et al. 2012; Lindberg et al. $2012 \mathrm{a}, \mathrm{b})$. Tumor necrosis factor $\alpha(\mathrm{TNF}-\alpha)$ signaling has both positive and negative effects on neurogenesis in vivo, because TNF receptor (TNFR)- 1 and TNF- $\alpha$-deficient animals have elevated baseline neurogenesis in the hippocampus, whereas absence of TNFR-2 decreases baseline neurogenesis (Chen and Palmer 2013). Other peptide factors, such as FGF-2, VEGF, and pituitary adenylate cyclase-activating polypeptide (PACAP) show both proliferative and neurotrophic activity (Zhu et al. 2003; Mercer et al. 2004; Schänzer et al. 2004; Ohta et al. 2006; Fournier et al. 2012). On the other hand, erythropoietin, G-CSF, and insulin-like growth factor (IGF)-1 have been shown to increase neurogenesis through their survival-promoting capacity 
Control of Cell Survival in Adult Neurogenesis

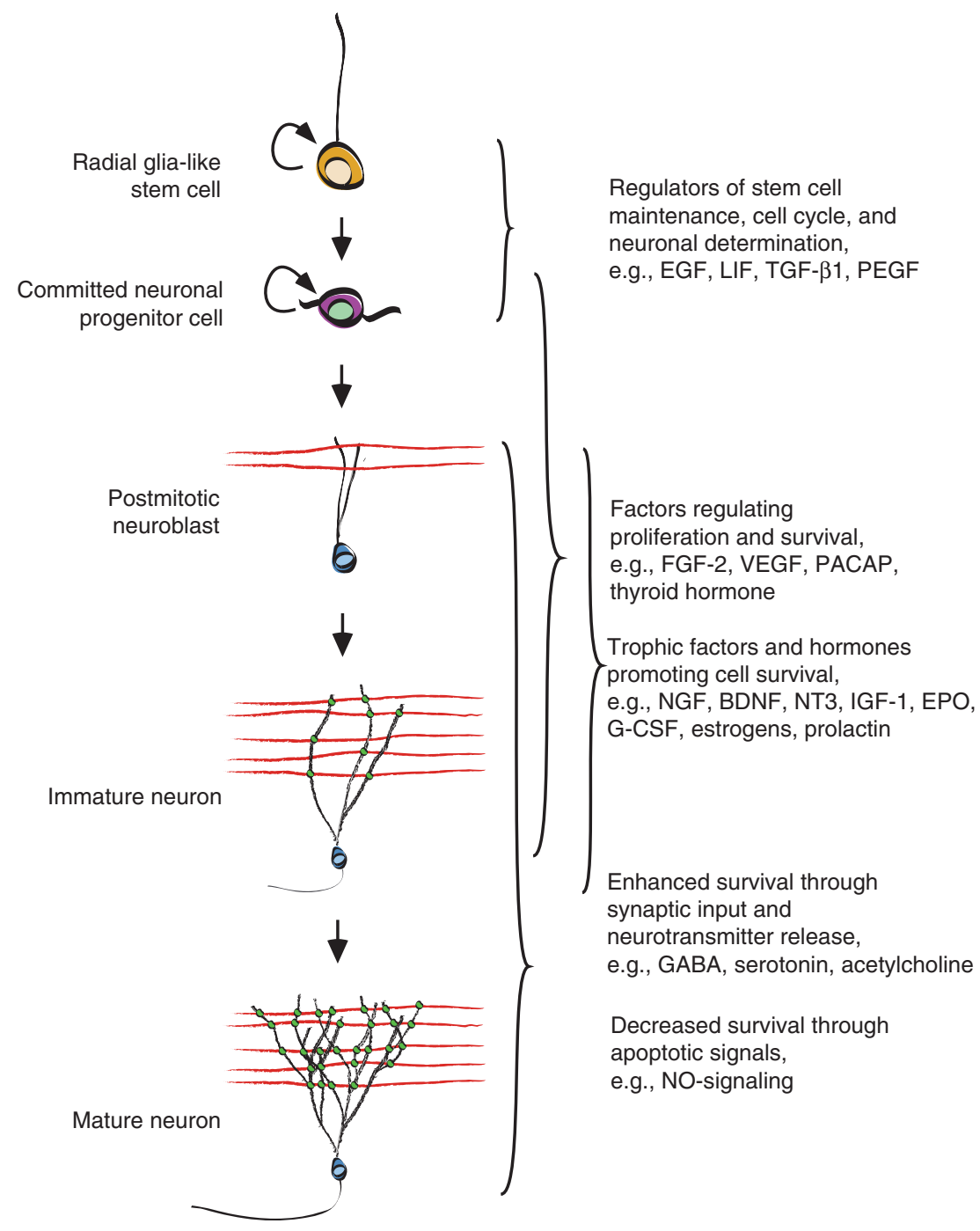

Figure 2. A multitude of factors regulates adult neurogenesis by controlling proliferation, fate determination, and survival of cells. Trophic support is required at all stages during development, from stem cell to neuron, and depletion of the stem-cell pool or apoptotic cell death may significantly reduce the amount of new neurons. Neurotransmitter and synaptic influences are detected at early progenitor stages, indicating a strong influence of the preexisting network on neuronal maturation in the adult brain. EGF, Epidermal growth factor; LIF, leukemia inhibitory factor; TGF- $\beta 1$, transforming growth factor $\beta 1$; PEGF, platelet-derived endothelial cell growth factor; FGF-2, fibroblast growth factor 2; VEGF, vascular endothelial growth factor; NT3, neurotrophin 3; IGF-1, insulin-like growth factor 1; EPO, erythropoietin; G-CSF, granulocyte colony-stimulating factor; GABA, $\gamma$-aminobutyric acid; $\mathrm{NO}$, nitric oxide.

(Åberg et al. 2000; Shingo et al. 2001; Schneider et al. 2005; Lichtenwalner et al. 2006). Storeoperated calcium channels (SOCS)-2 have been found to interact with the cytoplasmic domain of IGF-1 receptor and are thought to be involved in the regulation of IGF-1-recep- tor-mediated cell signaling. Transgenic mice overexpressing SOCS-2 show increased survival of adult-born hippocampal neurons, which correlates with improved performance in a hippocampal-dependent cognitive task (Ransome and Turnley 2008). 
H.G. Kuhn

\section{Hormones}

Hormonal signals control many aspects of neuronal development, including cell survival. It is, therefore, no surprise that adult neurogenesis is under strong hormonal influence. In short, stress hormones negatively regulate the number of new neurons by reducing proliferation as well as survival of progenitor cells (for more details, see Lucassen et al. 2010). Gonadal hormones and neurosteroids, on the other hand, stimulate the generation of new neurons (Karishma and Herbert 2002; Mayo et al. 2005; Galea et al. 2006). Steroid hormones act via nuclear hormone receptors, which bind to promoter regions in key genes for neuronal survival. $\mathrm{BDNF}$ and the Bcl-2 gene family are downstream targets from steroid hormone receptor activation (Almeida et al. 2000; Charalampopoulos et al. 2006; Scharfman and MacLusky 2006; Yao et al. 2007). Signaling through thyroid hormone and retinoic acid receptors appears to have a strong stimulatory effect on proliferation and survival of neuronal progenitor cells and appears to be important for maintaining postnatal and adult neurogenesis (Ambrogini et al. 2005; Desouza et al. 2005; Lemkine et al. 2005; Wang et al. 2005; Jacobs et al. 2006; Kornyei et al. 2007). Thyroid hormone receptor (TR)- $\alpha 1$-null mice show a significant increase in DCX-positive cells and increased survival of bromodeoxyuridinepositive cells compared with wild-type controls (Kapoor et al. 2010). TR- $\alpha 2$-null mice, on the other hand, show significantly less survival of newly generated cells and decreased numbers of polysialylated neuronal cell-adhesion molecule (PSA-NCAM)- and NeuroD-positive progenitor cells, suggesting negative effects on early postmitotic progenitors (Kapoor et al. 2010).

\section{NEUROTRANSMITTERS AND SYNAPTIC ACTIVITY}

As immature neurons strive to integrate into functional networks, neuronal communication becomes an important survival-promoting factor. Neural progenitor cells receive neurotransmitter input at an early stage while still undergoing cell division. It appears that neurotransmitters, such as $\gamma$-aminobutyric acid
(GABA), glutamate, acetylcholine, and serotonin, which are released in or near the neurogenic regions, are involved in adult neurogenesis mainly via regulation of cell-cycle entry and exit (for review, see Berg et al. 2013). This section focuses specifically on the effects of neurotransmitters on progenitor cell survival.

\section{GABA}

Although GABA is the main inhibitory neurotransmitter for mature neurons, it can act as a trophic factor for immature neurons and progenitor cells through $\mathrm{Cl}^{-}$-mediated depolarization. $\mathrm{GABA}_{\mathrm{A}}$ receptor activation inhibits proliferation and up-regulates neuronal determination factors, such as NeuroD, which stimulates cell-cycle exit and neuronal differentiation (for review, see Dieni et al. 2012). Fewer details are known about the effects of GABA on apoptosis of newly generated cells, although GABA depolarization has been shown to lead to cell death in 1- to 2-week-old cells, an effect that is rescued by CREB signaling (Jagasia et al. 2009). It is quite likely that mechanisms of synaptic integration induce cell survival in the hippocampus.

\section{Glutamate}

Reduced glutamatergic input via entorhinal cortex lesion or treatment with both competitive and noncompetitive NMDA receptor antagonists stimulated the proliferation of granule cell precursors and subsequent production of new granule cells (Cameron et al. 1995), although possibly in response to significant cell death. In contrast, a cell-specific knockout of the NMDA NR1 subunit in adult-born neurons of the dentate gyrus dramatically decreased their survival (Tashiro et al. 2006). Ionotropic and metabotropic glutamate receptors are also capable of modulating adult hippocampal neurogenesis (Bernabeu and Sharp 2000; Yoshimizu and Chaki 2004).

\section{Acetylcholine}

Lesions of the basal forebrain cholinergic system lead to significantly reduced survival rates of 
newly generated cells in the hippocampus and OB despite no changes in proliferation of progenitor cells (Cooper-Kuhn et al. 2004; Mohapel et al. 2005). Neuronally committed progenitors express multiple acetylcholine receptor subunits and make contact with cholinergic fibers (Kaneko et al. 2006). Pharmacological alterations in cholinergic signaling confirmed the positive influence of acetylcholine on hippocampal neurogenesis (Kaneko et al. 2006; Kotani et al. 2006), and in knockout mice for the nicotinic acetylcholine receptor $\alpha$ containing the $\alpha 7$ subunit, adult-born neurons developed less complex dendritic trees. These neurons appeared to be more immature, as indicated by a prolonged period of GABAergic depolarization. They also received less synaptic input and were more prone to undergo developmental cell death (Campbell et al. 2010).

\section{Serotonin}

Almost all antidepressants, which act through enhancement of serotonergic neurotransmission, stimulate hippocampal granule cell production. Chronic depletion of serotonin reduces neurogenesis (Brezun and Daszuta 1999), whereas antidepressants up-regulate neurotrophic factors CREB and Bcl-2, which suggests a survival-promoting effect of serotonin (Nibuya et al. 1995, 1996; Chen et al. 2007).

Nonclassical neurotransmitters are also potent regulators of adult neurogenesis. Neuropeptide $Y$ positively regulates hippocampal and SVZ cell proliferation (Howell et al. 2005, 2007; Stanic et al. 2008; Thiriet et al. 2011), whereas substance $\mathrm{P}$ and nitric oxide signaling appear to be detrimental to adult neurogenesis by repressing survival signals, such as BDNF and phosphorylated ( $\mathrm{p}$ )CREB signaling (Morcuende et al. 2003; Packer et al. 2003; Reif et al. 2004; Zhu et al. 2006).

\section{SYNAPTIC ACTIVITY AND SURVIVAL}

Synapse formation is a critical step in the survival of newly formed neurons, because targetderived factors are transported from the synapse to the soma to influence apoptotic signaling. In the $\mathrm{OB}$ neurogenesis system, the majority of dying cells have already matured to the point of forming dendritic spines and have the potential to receive synaptic input (Petreanu and Alvarez-Buylla 2002). Their survival seems to be very much dependent on sensory input (Corotto et al. 1994; Petreanu and Alvarez-Buylla 2002; Rochefort et al. 2002). Increased cell survival is observed under olfactory learning conditions, with higher numbers of surviving new neurons in more activated glomeruli (Alonso et al. 2006). Using in vivo multiphoton microscopy, it was shown that the loss and replacement of periglomerular neurons in the $\mathrm{OB}$ was highly specific, leading to recruitment of new cells into vacant spots within the glomeruli (Sawada et al. 2011). Similarly, in the dentate gyrus, neuronal activity within a short, critical time window of about 3 weeks after neuronal birth seems to determine the survival and resulting formation of new circuits. This critical period is associated with a high degree of morphological changes in new neurons, including synapse formation and NMDA receptor NR1 expression (Tashiro et al. 2006).

\section{CELL DEATH AND PROLIFERATION}

A large number of progenitor cells is eliminated during proliferation and maturation and thus it is no surprise that preventing activation of the cell-death cascade by overexpression of Bcl- 2 or deletion of BAX leads to an increase in neurogenesis (Sun et al. 2004; Kuhn et al. 2005). But, an interesting aspect in neurogenesis regulation is the question whether cell death triggers changes in proliferation or vice versa. Manipulations that induce neuronal cell death, such as high levels of cortisol or ischemia, also stimulate cell-cycle entry. Moreover, differentiated neurons, when forced to enter cell cycle, undergo apoptotic cell death (for review, see Liu and Greene 2001). Nevertheless, is progenitor proliferation a direct result of the "vacant spot"? The most direct evidence contradicting this hypothesis comes from Bax-deficient and Bcl-2overexpressing mice, in which a decrease in cell death did not lead to changes in proliferation (Sun et al. 2004; Kuhn et al. 2005). In contrast, 
decreased $S$ phase entry in mice deficient for the cell-cycle-activator protein E2F1 leads to decreased cell death (Cooper-Kuhn et al. 2002), indicating that cell-death regulation during adult neurogenesis occurs downstream from proliferative signals.

\section{MICROGLIA SIGNALING}

Apoptosis can be externally induced through death receptors, such as Fas or Toll-like receptors (TLRs), during inflammatory responses that involve microglia and/or T-cell activation. It was assumed that activated immune cells do not play a major role in the intact brain, because inflammatory signals are largely absent and microglia remain unchallenged (Ekdahl et al. 2003). However, this view was contested by a study in which CNS-specific autoimmune $\mathrm{T}$ cells cross talked with resident microglia to stimulate progenitor proliferation in a model of environmental stimulation (Ziv et al. 2006). In this study, T-cell deficiency also induced decreased BDNF and IGF-1 levels, thereby possibly influencing cell survival.

TLRs are innate immune receptors that have recently emerged as regulators of neuronal survival and developmental neuroplasticity. TLR3-deficient mice show increased hippocampal neurogenesis and elevated levels of the transcription factor CREB, suggesting that constitutive TLR-3 signaling negatively regulates cell maturation and survival (Okun et al. 2010). TLR-2 deficiency was shown to impair dentate gyrus neurogenesis in adult mice, whereas the absence of TLR-4 resulted in enhanced proliferation, differentiation, and survival of new neurons (Rolls et al. 2007).

Although activated microglia influence survival mechanisms in adult neurogenesis in situations of inflammation and increased immune responses, nonactivated microglia might also play an important role. The large amount of developmental cell death in the adult dentate gyrus and SVZ/OB system requires rapid and efficient phagocytosis of apoptotic cell bodies, which is performed by nonactivated, ramified microglia (Sierra et al. 2010; Lazarini et al. 2012).

\section{SUMMARY}

Naturally occurring cell death claims more than half of the differentiating neurons in the adult brain. Their survival depends on paracrine and target-derived substances with neurotrophic activity, afferent synaptic activity, cell-cell and cell-matrix interactions, as well as hormonal and other blood-borne signals. An infinite combination of factors can serve to rescue or influence the survival of immature neurons. As cells transition through a several-month-long differentiation and integration period, the fine balance of signals is easily disrupted at many points along the way.

\section{REFERENCES}

Åberg MA, Åberg ND, Hedbacker H, Oscarsson J, Eriksson PS. 2000. Peripheral infusion of IGF-I selectively induces neurogenesis in the adult rat hippocampus. J Neurosci 20: 2896-2903.

Acheson A, Lindsay RM. 1996. Non target-derived roles of the neurotrophins. Philos Trans R Soc Lond B Biol Sci 351: 417-422.

Almeida OF, Conde GL, Crochemore C, Demeneix BA, Fischer D, Hassan AH, Meyer M, Holsboer F, Michaelidis TM. 2000. Subtle shifts in the ratio between proand antiapoptotic molecules after activation of corticosteroid receptors decide neuronal fate. FASEB $J$ 14: 779-790.

Alonso M, Viollet C, Gabellec MM, Meas-Yedid V, OlivoMarin JC, Lledo PM. 2006. Olfactory discrimination learning increases the survival of adult-born neurons in the olfactory bulb. J Neurosci 26: 10508-10513.

Altman J, Das GD. 1965. Autoradiographic and histological evidence of postnatal hippocampal neurogenesis in rats. J Comp Neurol 124: 319-335.

Ambrogini P, Cuppini R, Ferri P, Mancini C, Ciaroni S, Voci A, Gerdoni E, Gallo G. 2005. Thyroid hormones affect neurogenesis in the dentate gyrus of adult rat. Neuroendocrinology 81: 244-253.

Bayer SA. 1982. Changes in the total number of dentate granule cells in juvenile and adult rats: A correlated volumetric and ${ }^{3} \mathrm{H}$-thymidine autoradiographic study. Exp Brain Res 46: 315-323.

Bayer SA, Yackel JW, Puri PS. 1982. Neurons in the rat dentate gyrus granular layer substantially increase during juvenile and adult life. Science 216: 890-892.

Benraiss A, Chmielnicki E, Lerner K, Roh D, Goldman SA. 2001. Adenoviral brain-derived neurotrophic factor induces both neostriatal and olfactory neuronal recruitment from endogenous progenitor cells in the adult forebrain. J Neurosci 21: 6718-6731.

Berg DA, Belnoue L, Song H, Simon A. 2013. Neurotransmitter-mediated control of neurogenesis in the adult vertebrate brain. Development 140: 2548-2561. 
Bernabeu R, Sharp FR. 2000. NMDA and AMPA/kainate glutamate receptors modulate dentate neurogenesis and CA3 synapsin-I in normal and ischemic hippocampus. J Cereb Blood Flow Metab 20: 1669-1680.

Bernier PJ, Parent A. 1998. Bcl-2 protein as a marker of neuronal immaturity in postnatal primate brain. J Neurosci 18: 2486-2497.

Bernier PJ, Vinet J, Cossette M, Parent A. 2000. Characterization of the subventricular zone of the adult human brain: Evidence for the involvement of Bcl-2. Neurosci Res 37: 67-78

Biebl M, Cooper CM, Winkler J, Kuhn HG. 2000. Analysis of neurogenesis and programmed cell death reveals a selfrenewing capacity in the adult rat brain. Neurosci Lett 291: $17-20$.

Biebl M, Winner B, Winkler J. 2005. Caspase inhibition decreases cell death in regions of adult neurogenesis. Neuroreport 16: 1147-1150.

Brezun JM, Daszuta A. 1999. Depletion in serotonin decreases neurogenesis in the dentate gyrus and the subventricular zone of adult rats. Neuroscience 89: 999-1002.

Bryckaert M, Guillonneau X, Hecquet C, Courtois Y, Mascarelli F. 1999. Both FGF1 and Bcl-x synthesis are necessary for the reduction of apoptosis in retinal pigmented epithelial cells by FGF2: Role of the extracellular signalregulated kinase 2. Oncogene 18: 7584-7593.

Buckwalter MS, Yamane M, Coleman BS, Ormerod BK, Chin JT, Palmer T, Wyss-Coray T. 2006. Chronically increased transforming growth factor- $\beta 1$ strongly inhibits hippocampal neurogenesis in aged mice. Am J Pathol 169: 154-164.

Buss RR, Sun W, Oppenheim RW. 2006. Adaptive roles of programmed cell death during nervous system development. Annu Rev Neurosci 29: 1-35.

Cameron HA, McEwen BS, Gould E. 1995. Regulation of adult neurogenesis by excitatory input and NMDA receptor activation in the dentate gyrus. J Neurosci 15: 46874692.

Campbell NR, Fernandes CC, Halff AW, Berg DK. 2010. Endogenous signaling through $\alpha 7$-containing nicotinic receptors promotes maturation and integration of adultborn neurons in the hippocampus. J Neurosci 30: 87348744.

Cao XQ, Arai H, Ren YR, Oizumi H, Zhang N, Seike S, Furuya T, Yasuda T, Mizuno Y, Mochizuki H. 2006. Recombinant human granulocyte colony-stimulating factor protects against MPTP-induced dopaminergic cell death in mice by altering Bcl-2/Bax expression levels. $J$ Neurochem 99: 861-867.

Chan JP, Cordeira J, Calderon GA, Iyer LK, Rios M. 2008. Depletion of central BDNF in mice impedes terminal differentiation of new granule neurons in the adult hippocampus. Mol Cell Neurosci 39: 372-383.

Charalampopoulos I, Alexaki VI, Tsatsanis C, Minas V, Dermitzaki E, Lasaridis I, Vardouli L, Stournaras C, Margioris AN, Castanas E, et al. 2006. Neurosteroids as endogenous inhibitors of neuronal cell apoptosis in aging. Ann NY Acad Sci 1088: 139-152.

Chen Z, Palmer TD. 2013. Differential roles of TNFR1 and TNFR2 signaling in adult hippocampal neurogenesis. Brain Behav Immun 30: 45-53.
Chen SJ, Kao CL, Chang YL, Yen CJ, Shui JW, Chien CS, Chen IL, Tsai TH, Ku HH, Chiou SH. 2007. Antidepressant administration modulates neural stem cell survival and serotoninergic differentiation through Bcl-2. Curr Neurovasc Res 4: 19-29.

Cooper-Kuhn CM, Kuhn HG. 2002. Is it all DNA repair? Methodological considerations for detecting neurogenesis in the adult brain. Brain Res Dev Brain Res 134: 13-21.

Cooper-Kuhn CM, Vroemen M, Brown J, Ye H, Thompson MA, Winkler J, Kuhn HG. 2002. Impaired adult neurogenesis in mice lacking the transcription factor E2F1. Mol Cell Neurosci 21: 312-323.

Cooper-Kuhn CM, Winkler J, Kuhn HG. 2004. Decreased neurogenesis after cholinergic forebrain lesion in the adult rat. J Neurosci Res 77: 155-165.

Corotto FS, Henegar JR, Maruniak JA. 1994. Odor deprivation leads to reduced neurogenesis and reduced neuronal survival in the olfactory bulb of the adult mouse. Neuroscience 61: 739-744.

Craig CG, Tropepe V, Morshead CM, Reynolds BA, Weiss S, van der Kooy D. 1996. In vivo growth factor expansion of endogenous subependymal neural precursor cell populations in the adult mouse brain. J Neurosci 16: 26492658.

Dayer AG, Ford AA, Cleaver KM, Yassaee M, Cameron HA. 2003. Short-term and long-term survival of new neurons in the rat dentate gyrus. J Comp Neurol 460: 563-572.

de Bilbao F, Guarin E, Nef P, Vallet P, Giannakopoulos P, Dubois-Dauphin M. 1999. Postnatal distribution of $c p p 32 /$ caspase 3 mRNA in the mouse central nervous system: An in situ hybridization study. J Comp Neurol 409: 339-357.

Desire L, Courtois Y, Jeanny JC. 2000. Endogenous and exogenous fibroblast growth factor 2 support survival of chick retinal neurons by control of neuronal neuronal $b c l-x_{L}$ and $b c l-2$ expression through a fibroblast growth factor receptor 1- and Erk-dependent pathway. J Neurochem 75: 151-163.

Desouza LA, Ladiwala U, Daniel SM, Agashe S, Vaidya RA, Vaidya VA. 2005. Thyroid hormone regulates hippocampal neurogenesis in the adult rat brain. Mol Cell Neurosci 29: 414-426.

Dieni CV, Chancey JH, Overstreet-Wadiche LS. 2012. Dynamic functions of GABA signaling during granule cell maturation. Front Neural Circuits 6: 113.

Ekdahl CT, Zhu C, Bonde S, Bahr BA, Blomgren K, Lindvall O. 2003. Death mechanisms in status epilepticus-generated neurons and effects of additional seizures on their survival. Neurobiol Dis 14: 513-523.

Fournier NM, Lee B, Banasr M, Elsayed M, Duman RS. 2012. Vascular endothelial growth factor regulates adult hippocampal cell proliferation through MEK/ERK- and PI3K/Akt-dependent signaling. Neuropharmacology 63: $642-652$.

Frielingsdorf H, Simpson DR, Thal LJ, Pizzo DP. 2007. Nerve growth factor promotes survival of new neurons in the adult hippocampus. Neurobiol Dis 26: 47-55.

Galea LA, Spritzer MD, Barker JM, Pawluski JL. 2006. Gonadal hormone modulation of hippocampal neurogenesis in the adult. Hippocampus 16: 225-232. 
H.G. Kuhn

Gemma C, Bachstetter AD, Cole MJ, Fister M, Hudson C Bickford PC. 2007. Blockade of caspase-1 increases neurogenesis in the aged hippocampus. Eur J Neurosci 26: 2795-2803.

Gomez-Gaviro MV, Scott CE, Sesay AK, Matheu A, Booth S, Galichet C, Lovell-Badge R. 2012. Betacellulin promotes cell proliferation in the neural stem cell niche and stimulates neurogenesis. Proc Natl Acad Sci 109: 1317-1322.

Gomez-Pinilla F, Lee JW, Cotman CW. 1992. Basic FGF in adult rat brain: Cellular distribution and response to entorhinal lesion and fimbria-fornix transection. J Neurosci 12: $345-355$.

Gould E, Woolley CS, McEwen BS. 1991. Naturally occurring cell death in the developing dentate gyrus of the rat. $J$ Comp Neurol 304: 408-418.

Herold S, Jagasia R, Merz K, Wassmer K, Lie DC. 2011. CREB signalling regulates early survival, neuronal gene expression and morphological development in adult subventricular zone neurogenesis. Mol Cell Neurosci 46: 7988.

Howell OW, Doyle K, Goodman JH, Scharfman HE, Herzog H, Pringle A, Beck-Sickinger AG, Gray WP. 2005. Neuropeptide $Y$ stimulates neuronal precursor proliferation in the post-natal and adult dentate gyrus. J Neurochem 93: $560-570$.

Howell OW, Silva S, Scharfman HE, Sosunov AA, Zaben M, Shatya A, McKhann G II, Herzog H, Laskowski A, Gray WP. 2007. Neuropeptide Y is important for basal and seizure-induced precursor cell proliferation in the hippocampus. Neurobiol Dis 26: 174-188.

Jacobs S, Lie DC, DeCicco KL, Shi Y, DeLuca LM, Gage FH, Evans RM. 2006. Retinoic acid is required early during adult neurogenesis in the dentate gyrus. Proc Natl Acad Sci 103: 3902-3907.

Jagasia R, Steib K, Englberger E, Herold S, Faus-Kessler T, Saxe M, Gage FH, Song H, Lie DC. 2009. GABA-cAMP response element-binding protein signaling regulates maturation and survival of newly generated neurons in the adult hippocampus. J Neurosci 29: 7966-7977.

Jin K, Mao XO, Sun Y, Xie L, Greenberg DA. 2002. Stem cell factor stimulates neurogenesis in vitro and in vivo. J Clin Invest 110: 311-319.

Kaneko N, Okano H, Sawamoto K. 2006. Role of the cholinergic system in regulating survival of newborn neurons in the adult mouse dentate gyrus and olfactory bulb. Genes Cells 11: 1145-1159.

Kaplan MS, McNelly NA, Hinds JW. 1985. Population dynamics of adult-formed granule neurons of the rat olfactory bulb. J Comp Neurol 239: 117-125.

Kapoor R, van Hogerlinden M, Wallis K, Ghosh H, Nordstrom K, Vennstrom B, Vaidya VA. 2010. Unliganded thyroid hormone receptor $\alpha 1$ impairs adult hippocampal neurogenesis. FASEB J 24: 4793-4805.

Karishma KK, Herbert J. 2002. Dehydroepiandrosterone (DHEA) stimulates neurogenesis in the hippocampus of the rat, promotes survival of newly formed neurons and prevents corticosterone-induced suppression. Eur J Neurosci 16: 445-453.

Kim WR, Kim Y, Eun B, Park OH, Kim H, Kim K, Park CH, Vinsant S, Oppenheim RW, Sun W. 2007. Impaired migration in the rostral migratory stream but spared olfactory function after the elimination of programmed cell death in Bax knock-out mice. J Neurosci 27: 14392 14403.

Kim WR, Park OH, Choi S, Choi SY, Park SK, Lee KJ, Rhyu IJ, Kim H, Lee YK, Kim HT, et al. 2009. The maintenance of specific aspects of neuronal function and behavior is dependent on programmed cell death of adult-generated neurons in the dentate gyrus. Eur J Neurosci 29: 14081421.

Kim WR, Chun SK, Kim TW, Kim H, Ono K, Takebayashi H, Ikenaka K, Oppenheim RW, Sun W. 2011. Evidence for the spontaneous production but massive programmed cell death of new neurons in the subcallosal zone of the postnatal mouse brain. Eur J Neurosci 33: 599-611.

Kornyei Z, Gocza E, Ruhl R, Orsolits B, Voros E, Szabo B, Vagovits B, Madarasz E. 2007. Astroglia-derived retinoic acid is a key factor in glia-induced neurogenesis. FASEB $J$ 21: 2496-2509.

Kotani S, Yamauchi T, Teramoto T, Ogura H. 2006. Pharmacological evidence of cholinergic involvement in adult hippocampal neurogenesis in rats. Neuroscience 142: 505-514.

Kuhn HG, Winkler J, Kempermann G, Thal LJ, Gage FH. 1997. Epidermal growth factor and fibroblast growth factor-2 have different effects on neural progenitors in the adult rat brain. J Neurosci 17: 5820-5829.

Kuhn HG, Biebl M, Wilhelm D, Li M, Friedlander RM, Winkler J. 2005. Increased generation of granule cells in adult Bcl-2-overexpressing mice: A role for cell death during continued hippocampal neurogenesis. Eur J Neurosci 22: 1907-1915.

Lagace DC, Whitman MC, Noonan MA, Ables JL, DeCarolis NA, Arguello AA, Donovan MH, Fischer SJ, Farnbauch LA, Beech RD, et al. 2007. Dynamic contribution of nestin-expressing stem cells to adult neurogenesis. J Neurosci 27: $12623-12629$

Lazarini F, Gabellec MM, Torquet N, Lledo PM. 2012. Early activation of microglia triggers long-lasting impairment of adult neurogenesis in the olfactory bulb. J Neurosci 32: 3652-3664.

Lemkine GF, Raj A, Alfama G, Turque N, Hassani Z, AlegriaPrevot O, Samarut J, Levi G, Demeneix BA. 2005. Adult neural stem cell cycling in vivo requires thyroid hormone and its $\alpha$ receptor. FASEB J 19: 863-865.

Lewin GR, Barde YA. 1996. Physiology of the neurotrophins. Annu Rev Neurosci 19: 289-317.

Lichtenwalner RJ, Forbes ME, Sonntag WE, Riddle DR. 2006. Adult-onset deficiency in growth hormone and insulin-like growth factor-I decreases survival of dentate granule neurons: Insights into the regulation of adult hippocampal neurogenesis. J Neurosci Res 83: 199-210.

Lindberg OR, Brederlau A, Jansson A, Nannmark U, Cooper-Kuhn C, Kuhn HG. 2012a. Characterization of epidermal growth factor-induced dysplasia in the adult rat subventricular zone. Stem Cells Dev 21: 1356-1366.

Lindberg OR, Persson A, Brederlau A, Shabro A, Kuhn HG. 2012b. EGF-induced expansion of migratory cells in the rostral migratory stream. PLoS ONE 7: e46380.

Lindsten T, Golden JA, Zong WX, Minarcik J, Harris MH, Thompson CB. 2003. The proapoptotic activities of Bax and Bak limit the size of the neural stem cell pool. $J$ Neurosci 23: 11112-11119. 
Liu DX, Greene LA. 2001. Neuronal apoptosis at the $\mathrm{G}_{1} / \mathrm{S}$ cell cycle checkpoint. Cell Tissue Res 305: 217-228.

Lucassen PJ, Meerlo P, Naylor A, van Dam AM, Dayer A, Fuchs E, Oomen C, Czeh B. 2010. Regulation of adult neurogenesis by stress, sleep disruption, exercise and inflammation: Implications for depression and antidepressant action. Eur Neuropsychopharmacology 20: 1-17.

Mayo W, Lemaire V, Malaterre J, Rodriguez JJ, Cayre M, Stewart MG, Kharouby M, Rougon G, Le Moal M, Piazza PV, et al. 2005. Pregnenolone sulfate enhances neurogenesis and PSA-NCAM in young and aged hippocampus. Neurobiol Aging 26: 103-114.

Mercer A, Ronnholm H, Holmberg J, Lundh H, Heidrich J, Zachrisson O, Ossoinak A, Frisen J, Patrone C. 2004. PACAP promotes neural stem cell proliferation in adult mouse brain. J Neurosci Res 76: 205-215.

Milosevic J, Maisel M, Wegner F, Leuchtenberger J, Wenger RH, Gerlach M, Storch A, Schwarz J. 2007. Lack of hypoxia-inducible factor-1 $\alpha$ impairs midbrain neural precursor cells involving vascular endothelial growth factor signaling. J Neurosci 27: 412-421.

Mohapel P, Leanza G, Kokaia M, Lindvall O. 2005. Forebrain acetylcholine regulates adult hippocampal neurogenesis and learning. Neurobiol Aging 26: 939-946.

Morcuende S, Gadd CA, Peters M, Moss A, Harris EA, Sheasby A, Fisher AS, De Felipe C, Mantyh PW, Rupniak $\mathrm{NM}$, et al. 2003. Increased neurogenesis and brain-derived neurotrophic factor in neurokinin-1 receptor gene knockout mice. Eur J Neurosci 18: 1828-1836.

Muramatsu R, Ikegaya Y, Matsuki N, Koyama R. 2007. Neonatally born granule cells numerically dominate adult mice dentate gyrus. Neuroscience 148: 593-598.

Nibuya M, Morinobu S, Duman RS. 1995. Regulation of BDNF and trkB mRNA in rat brain by chronic electroconvulsive seizure and antidepressant drug treatments. J Neurosci 15: 7539-7547.

Nibuya M, Nestler EJ, Duman RS. 1996. Chronic antidepressant administration increases the expression of cAMP response element binding protein (CREB) in rat hippocampus. J Neurosci 16: 2365-2372.

Ninkovic J, Mori T, Gotz M. 2007. Distinct modes of neuron addition in adult mouse neurogenesis. J Neurosci 27: 10906-10911.

Ohta S, Gregg C, Weiss S. 2006. Pituitary adenylate cyclaseactivating polypeptide regulates forebrain neural stem cells and neurogenesis in vitro and in vivo. $J$ Neurosci Res 84: 1177-1186.

Okun E, Griffioen K, Barak B, Roberts NJ, Castro K, Pita MA, Cheng A, Mughal MR, Wan R, Ashery U, et al. 2010. Toll-like receptor 3 inhibits memory retention and constrains adult hippocampal neurogenesis. Proc Natl Acad Sci 107: 15625-15630.

Oppenheim RW. 1989. The neurotrophic theory and naturally occurring motoneuron death. Trends Neurosci 12: 252-255.

Oppenheim RW. 1991. Cell death during development of the nervous system. Annu Rev Neurosci 14: 453-501.

Packer MA, Stasiv Y, Benraiss A, Chmielnicki E, Grinberg A, Westphal H, Goldman SA, Enikolopov G. 2003. Nitric oxide negatively regulates mammalian adult neurogenesis. Proc Natl Acad Sci 100: 9566-9571.
Petreanu L, Alvarez-Buylla A. 2002. Maturation and death of adult-born olfactory bulb granule neurons: Role of olfaction. J Neurosci 22: 6106-6113.

Ramirez-Castillejo C, Sanchez-Sanchez F, Andreu-Agullo C, Ferron SR, Aroca-Aguilar JD, Sanchez P, Mira H, Escribano J, Farinas I. 2006. Pigment epithelium-derived factor is a niche signal for neural stem cell renewal. Nat Neurosci 9: 331-339.

Ransome MI, Turnley AM. 2008. Growth hormone signaling and hippocampal neurogenesis: Insights from genetic models. Hippocampus 18: 1034-1050.

Reif A, Schmitt A, Fritzen S, Chourbaji S, Bartsch C, Urani A, Wycislo M, Mossner R, Sommer C, Gass P, et al. 2004. Differential effect of endothelial nitric oxide synthase (NOS-III) on the regulation of adult neurogenesis and behaviour. Eur J Neurosci 20: 885-895.

Renault TT, Teijido O, Antonsson B, Dejean LM, Manon S. 2013. Regulation of Bax mitochondrial localization by $\mathrm{Bcl}-2$ and Bcl- $\mathrm{x}_{\mathrm{L}}$ : Keep your friends close but your enemies closer. Int J Biochem Cell Biol 45: 64-67.

Rios-Munoz W, Soto I, Duprey-Diaz MV, Blagburn J, Blanco RE. 2005. Fibroblast growth factor 2 applied to the optic nerve after axotomy increases Bcl-2 and decreases Bax in ganglion cells by activating the extracellular signal-regulated kinase signaling pathway. J Neurochem 93: 14221433.

Rochefort C, Gheusi G, Vincent JD, Lledo PM. 2002. Enriched odor exposure increases the number of newborn neurons in the adult olfactory bulb and improves odor memory. J Neurosci 22: 2679-2689.

Rolls A, Shechter R, London A, Ziv Y, Ronen A, Levy R, Schwartz M. 2007. Toll-like receptors modulate adult hippocampal neurogenesis. Nat Cell Biol 9: 1081-1088.

Rossi C, Angelucci A, Costantin L, Braschi C, Mazzantini M, Babbini F, Fabbri ME, Tessarollo L, Maffei L, Berardi N, et al. 2006. Brain-derived neurotrophic factor (BDNF) is required for the enhancement of hippocampal neurogenesis following environmental enrichment. Eur J Neurosci 24: $1850-1856$.

Sahay A, Scobie KN, Hill AS, O’Carroll CM, Kheirbek MA, Burghardt NS, Fenton AA, Dranovsky A, Hen R. 2011. Increasing adult hippocampal neurogenesis is sufficient to improve pattern separation. Nature 472: 466-470.

Sasaki T, Kitagawa K, Yagita Y, Sugiura S, Omura-Matsuoka E, Tanaka S, Matsushita K, Okano H, Tsujimoto Y, Hori M. 2006. Bcl2 enhances survival of newborn neurons in the normal and ischemic hippocampus. J Neurosci Res 84: 1187-1196.

Sawada M, Kaneko N, Inada H, Wake H, Kato Y, Yanagawa Y, Kobayashi K, Nemoto T, Nabekura J, Sawamoto K. 2011. Sensory input regulates spatial and subtype-specific patterns of neuronal turnover in the adult olfactory bulb. $J$ Neurosci 31: 11587-11596.

Schänzer A, Wachs FP, Wilhelm D, Acker T, Cooper-Kuhn CM, Beck H, Winkler J, Aigner L, Plate KH, Kuhn HG. 2004. Direct stimulation of adult neural stem cells in vitro and neurogenesis in vivo by vascular endothelial growth factor. Brain Pathol 14: 237-248.

Scharfman HE, MacLusky NJ. 2006. Estrogen and brainderived neurotrophic factor (BDNF) in hippocampus: Complexity of steroid hormone-growth factor interac- 
H.G. Kuhn

tions in the adult CNS. Front Neuroendocrinol 27: 415435.

Scharfman H, Goodman J, Macleod A, Phani S, Antonelli C, Croll S. 2005. Increased neurogenesis and the ectopic granule cells after intrahippocampal BDNF infusion in adult rats. Exp Neurol 192: 348-356.

Schneider A, Kruger C, Steigleder T, Weber D, Pitzer C, Laage R, Aronowski J, Maurer MH, Gassler N, Mier W, et al. 2005. The hematopoietic factor G-CSF is a neuronal ligand that counteracts programmed cell death and drives neurogenesis. J Clin Invest 115: 2083-2098.

Seki T. 2002. Expression patterns of immature neuronal markers PSA-NCAM, CRMP-4 and NeuroD in the hippocampus of young adult and aged rodents. J Neurosci Res 70: 327-334.

Shi J, Parada LF, Kernie SG. 2005. Bax limits adult neural stem cell persistence through caspase and IP3 receptor activation. Cell Death Differ 12: 1601-1612.

Shimazu K, Zhao M, Sakata K, Akbarian S, Bates B, Jaenisch R, Lu B. 2006. NT-3 facilitates hippocampal plasticity and learning and memory by regulating neurogenesis. Learn Mem 13: 307-315.

Shingo T, Sorokan ST, Shimazaki T, Weiss S. 2001. Erythropoietin regulates the in vitro and in vivo production of neuronal progenitors by mammalian forebrain neural stem cells. J Neurosci 21: 9733-9743.

Sierra A, Encinas JM, Deudero JJ, Chancey JH, Enikolopov G, Overstreet-Wadiche LS, Tsirka SE, Maletic-Savatic M. 2010. Microglia shape adult hippocampal neurogenesis through apoptosis-coupled phagocytosis. Cell Stem Cell 7: 483-495.

Solaroglu I, Tsubokawa T, Cahill J, Zhang JH. 2006. Antiapoptotic effect of granulocyte-colony stimulating factor after focal cerebral ischemia in the rat. Neuroscience 143: 965-974.

Stanic D, Paratcha G, Ledda F, Herzog H, Kopin AS, Hokfelt T. 2008. Peptidergic influences on proliferation, migration, and placement of neural progenitors in the adult mouse forebrain. Proc Natl Acad Sci 105: 3610-3615.

Sun W, Winseck A, Vinsant S, Park OH, Kim H, Oppenheim RW. 2004. Programmed cell death of adult-generated hippocampal neurons is mediated by the proapoptotic gene Bax. J Neurosci 24: 11205-11213.

Tashiro A, Sandler VM, Toni N, Zhao C, Gage FH. 2006. NMDA-receptor-mediated, cell-specific integration of new neurons in adult dentate gyrus. Nature 442: 929933.

Thiriet N, Agasse F, Nicoleau C, Guegan C, Vallette F, Cadet JL, Jaber M, Malva JO, Coronas V. 2011. NPY promotes chemokinesis and neurogenesis in the rat subventricular zone. J Neurochem 116: 1018-1027.

Wachs FP, Winner B, Couillard-Despres S, Schiller T, Aigner R, Winkler J, Bogdahn U, Aigner L. 2006. Transforming growth factor- $\beta 1$ is a negative modulator of adult neurogenesis. J Neuropathol Exp Neurol 65: 358-370.
Wagner JP, Black IB, DiCicco-Bloom E. 1999. Stimulation of neonatal and adult brain neurogenesis by subcutaneous injection of basic fibroblast growth factor. J Neurosci 19: 6006-6016.

Wang TW, Zhang H, Parent JM. 2005. Retinoic acid regulates postnatal neurogenesis in the murine subventricular zone-olfactory bulb pathway. Development 132: 2721 2732.

Werner S, Unsicker K, von Bohlen und Halbach O. 2011. Fibroblast growth factor-2 deficiency causes defects in adult hippocampal neurogenesis, which are not rescued by exogenous fibroblast growth factor-2. J Neurosci Res 89: $1605-1617$.

Winner B, Cooper-Kuhn CM, Aigner R, Winkler J, Kuhn HG. 2002. Long-term survival and cell death of newly generated neurons in the adult rat olfactory bulb. Eur $J$ Neurosci 16: 1681-1689.

Yao M, Nguyen TV, Pike CJ. 2007. Estrogen regulates Bcl-w and Bim expression: Role in protection against $\beta$-amyloid peptide-induced neuronal death. J Neurosci 27: 1422-1433.

Yoshimizu T, Chaki S. 2004. Increased cell proliferation in the adult mouse hippocampus following chronic administration of group II metabotropic glutamate receptor antagonist, MGS0039. Biochem Biophys Res Commun 315: 493-496.

Zhang SJ, Zou M, Lu L, Lau D, Ditzel DA, Delucinge-Vivier C, Aso Y, Descombes P, Bading H. 2009. Nuclear calcium signaling controls expression of a large gene pool: Identification of a gene program for acquired neuroprotection induced by synaptic activity. PLoS Genet 5: e1000604.

Zhao M, Li D, Shimazu K, Zhou YX, Lu B, Deng CX. 2007. Fibroblast growth factor receptor-1 is required for longterm potentiation, memory consolidation, and neurogenesis. Biol Psychiatry 62: 381-390.

Zhu Y, Jin K, Mao XO, Greenberg DA. 2003. Vascular endothelial growth factor promotes proliferation of cortical neuron precursors by regulating E2F expression. FASEB J 17: 186-193.

Zhu XJ, Hua Y, Jiang J, Zhou QG, Luo CX, Han X, Lu YM, Zhu DY. 2006. Neuronal nitric oxide synthase-derived nitric oxide inhibits neurogenesis in the adult dentate gyrus by down-regulating cyclic AMP response element binding protein phosphorylation. Neuroscience 141: 827-836.

Zigova T, Pencea V, Wiegand SJ, Luskin MB. 1998. Intraventricular administration of BDNF increases the number of newly generated neurons in the adult olfactory bulb. Mol Cell Neurosci 11: 234-245.

Ziv Y, Ron N, Butovsky O, Landa G, Sudai E, Greenberg N, Cohen H, Kipnis J, Schwartz M. 2006. Immune cells contribute to the maintenance of neurogenesis and spatial learning abilities in adulthood. Nat Neurosci 9: 268-275. 


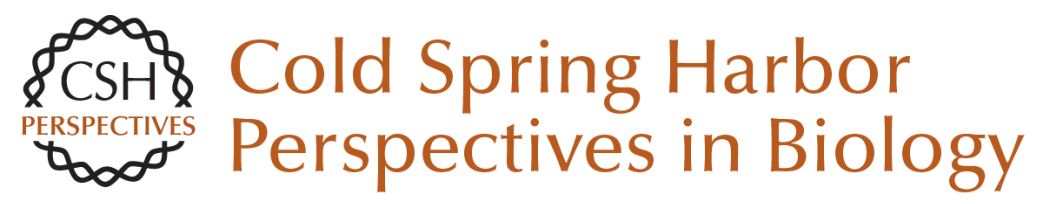

\section{Control of Cell Survival in Adult Mammalian Neurogenesis}

H. Georg Kuhn

Cold Spring Harb Perspect Biol 2015; doi: 10.1101/cshperspect.a018895 originally published online October 28, 2015

\section{Subject Collection Neurogenesis}

Adult Neurogenesis and Psychiatric Disorders Eunchai Kang, Zhexing Wen, Hongjun Song, et al.

Neuronal Circuitry Mechanisms Regulating Adult Mammalian Neurogenesis Juan Song, Reid H.J. Olsen, Jiaqi Sun, et al.

Neurogenesis in the Developing and Adult Brain

--Similarities and Key Differences

Magdalena Götz, Masato Nakafuku and David Petrik

Genetics and Epigenetics in Adult Neurogenesis Jenny Hsieh and Xinyu Zhao

The Adult Ventricular-Subventricular Zone (V-SVZ) and Olfactory Bulb (OB) Neurogenesis Daniel A. Lim and Arturo Alvarez-Buylla

Diversity of Neural Precursors in the Adult Mammalian Brain Michael A. Bonaguidi, Ryan P. Stadel, Daniel A. Berg, et al.

Detection and Phenotypic Characterization of Adult Neurogenesis $H$. Georg Kuhn, Amelia J. Eisch, Kirsty Spalding, et al.

Maturation and Functional Integration of New Granule Cells into the Adult Hippocampus Nicolas Toni and Alejandro F. Schinder
Adult Olfactory Bulb Neurogenesis

Pierre-Marie Lledo and Matt Valley

Adult Neurogenesis in Fish Julia Ganz and Michael Brand

In Vitro Models for Neurogenesis Hassan Azari and Brent A. Reynolds

Engineering of Adult Neurogenesis and Gliogenesis

Benedikt Berninger and Sebastian Jessberger

Computational Modeling of Adult Neurogenesis James B. Aimone

Control of Adult Neurogenesis by Short-Range Morphogenic-Signaling Molecules Youngshik Choe, Samuel J. Pleasure and Helena Mira

Adult Neurogenesis: An Evolutionary Perspective Gerd Kempermann

Epilepsy and Adult Neurogenesis

Sebastian Jessberger and Jack M. Parent

For additional articles in this collection, see http://cshperspectives.cshlp.org/cgi/collection/

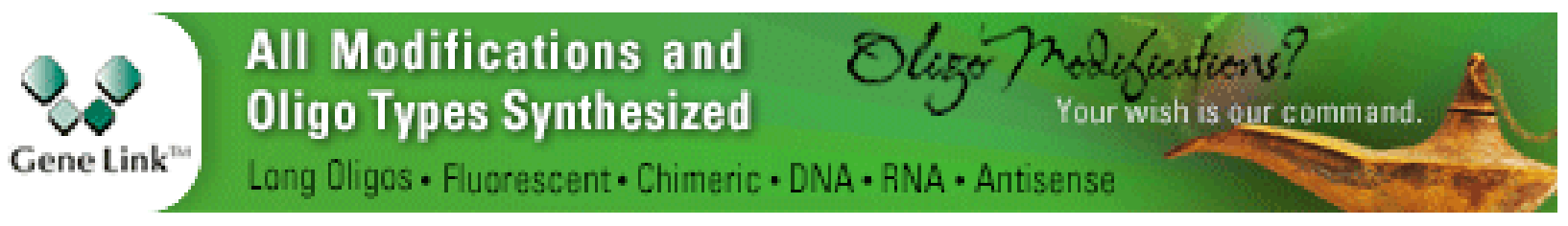


For additional articles in this collection, see http://cshperspectives.cshlp.org/cgi/collection/

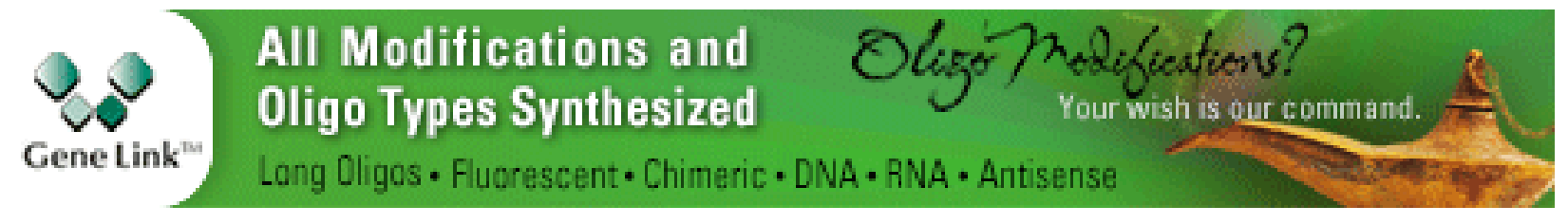

Copyright @ 2015 Cold Spring Harbor Laboratory Press; all rights reserved 